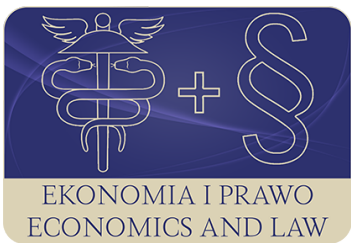

EKONOMIA I PRAWO. ECONOMICS AND LAW

Volume 20, Issue 3, September 2021

p-ISSN 1898-2255, e-ISSN 2392-1625

www.economicsandlaw.pl

ORIGINAL ARTICLE

received 25.08.2021; revised 25.09.2021; accepted 30.09.2021

Citation: Polasik, M., Widawski, P., Keler, G., \& Butor-Keler, A. (2021). Retail Payments Strategy for the EU versus the challenges of the payment sector. Ekonomia i Prawo. Economics and Law, 20(3), 617-640. https://doi.org/10.12775/EiP.2021.037.

\title{
Retail Payments Strategy for the EU versus the challenges of the payment sector
}

\section{MICHAE POLASIK}

corresponding author

Nicolaus Copernicus University in Toruń, Faculty of Economic Sciences and Management,

Department of Digital Economy and Finance, ul. Gagarina 13A, 87-100 Toruń, Poland

$\square$ michal.polasik@umk.pl

(D) orcid.org/0000-0002-7790-4839

\section{PAWEE WIDAWSKI}

University of Warsaw, Faculty of Law and Administration, Center for Regulation of Financial

Services and Technologies, Poland

$\square$ p.widawski@wpia.uw.edu.pl

(D) orcid.org/0000-0003-0457-360X

\section{GRZEGORZ KELER}

Nicolaus Copernicus University in Torun, Faculty of Economic Sciences and Management, Centre for Digital Economy and Finance, Poland

$\square$ grzegorz.keler@v.umk.pl

(D) orcid.org/0000-0003-2655-4135

\section{AGNIESZKA BUTOR-KELER}

SGH Warsaw School of Economics, Collegium of Business Administration, Institute of Corporate Finance and Investment, Poland

๑abutor@sgh.waw.pl

(D) orcid.org/0000-0002-2761-3144 


\begin{abstract}
Motivation: The payment services sector has become one of the main areas for the development of financial innovation and the key element of the digital economy. However, the payment services market in the European Union (called the European Payments Market) is still fragmented along national borders, insufficiently integrated, and facing several challenges. Therefore, the newly announced Retail Payments Strategy for the EU is a document of great importance for the future of the entire EU economy, and deserves in-depth study.

Aim: The purpose of this paper is to assess whether the trends and challenges identified by the European Commission in the Retail Payments Strategy, and the general directions and proposed actions presented in this document, appropriately reflect the challenges faced by the European payment market.

Results: A comparative analysis of the Strategy's assumptions and proposed actions was conducted, in relation to the identified challenges of the payment sector. The empirical data were derived from a survey of 202 experts from all EU member states, and the UK,

Norway and Switzerland, covering all types of bank and non-bank payment market players. The analysis confirmed that the Strategy identified the main challenges and opportunities, in line with the results of the expert survey: the need for further development of open banking; cross-border integration and development of instant payments systems; and ensuring access to the banking payment infrastructure, including contactless and NFC mobile payments. However, the proposed directions of action in selected areas have not been sufficiently rationalised, and most of the actions have been left to be specified in the future. In addition, the Strategy relies mostly on the use of regulatory tools that may limit innovativeness. Although the Commission and the surveyed experts agreed in recognising the challenges related to the increasing role of BigTechs in the payment sector, no comprehensive solution addressing the related challenges was proposed in the Strategy.
\end{abstract}

Keywords: Single Payments Market; payments strategy; open banking; PayTech; BigTech JEL: E42; G21; G23; G28; O33

\title{
1. Introduction
}

Within the last several years, selected European regulatory and standardisation initiatives have shaped the European retail payments market to a considerable extent. This process is closely connected with the objective of creating the Single Payments Market as a part of the Single Market for Financial Services. The latter is a critical element of the European Single Market and a realisation of a number of EU Treaty movements: these include the free movement of capital, which is closely related to free movement of services; and free movement of payments, which is inextricably linked to the movement of goods, services and capital (Mavromati, 2008). However, despite many years of efforts, a fully integrated EU payment services market has not yet been created.

Recent years have seen considerable improvements that can be ascribed mainly to the development of the Single Euro Payment Area (SEPA) and the harmonisation of laws governing retail payments - among others, Directive 2007/64/EC on payment services in the internal market (2007) - PSD1 
and Directive 2015/2366 on payment services in the internal market (2015) - PSD2. To a large extent, the EU payment market is still fragmented along national borders, as most domestic payment solutions based on cards or instant payments do not work cross-border (Communication COM/2020/592, 2020, hereinafter referred to as the Strategy, 2020)). In this regard, EU institutions, particularly the European Commission and the European Central Bank, ${ }^{1}$ have implemented or are planning a range of various activities aimed at the integration of this market. These actions have been described in the Strategy (2020). The Strategy outlines the challenges connected with the development of the EU payment market, and proposes respective actions to be taken to address them. Most of these actions are regulatory measures.

The payment market is constantly changing due to technological advances and innovations (Bech \& Hancock, 2020). Therefore, doubt arises as to the extent of regulatory intervention, and respectively the economic freedom that should be granted, for the market to achieve the goal of establishing a single payment market that would be highly integrated yet also competitive and innovative. In the dynamic ecosystem of payments, overregulation may cause deceleration of the technological development and innovation which naturally take place in the private sector (Blind et al., 2017).

The purpose of this paper is to assess whether the trends and challenges identified by European Commission, as well as the general directions and proposed actions presented in the Strategy, appropriately reflect the challenges faced by the European payment market. The specific goals of the research are to answer the following questions:

- Q1. Which objectives and related actions were considered as crucial by the European Commission in the Strategy?

- O2. What are the major challenges for participants in the European payment services sector?

- Q3. To what extent do the actions announced in the Strategy address the challenges faced by the payment services sector in the European Union? The article contains a comparative analysis of the challenges identified in the market experts (empirical) study, in relation to the actions proposed in the above-mentioned Strategy for the payment services market. The empirical results are based on a survey of 202 experts from all EU member states, and the United Kingdom, Norway and Switzerland. The sample includes experts employed in all types of institutions involved in the payment sector. It must be emphasised that, to the authors' knowledge, this paper is the first academic study on the new Strategy for the retail payment services sector in the European Union.

1 The integration of payment markets is actively supported by the European Central Bank, which is responsible for supervising the payment system as part of its scope of activity, laid down in the Treaty on the Functioning of the European Union (2012). Pursuant to Aritcle 127 (2) of the Treaty, one of the four basic tasks to be carried out by the European System of Central Banks (ESCB) is the promotion of the smooth operation of payment systems. 


\section{Stimulants and barriers to the payment services market: literature review}

The payment services market in the EU is subject to dynamic changes, which are mainly caused by technological innovations that enable the creation of new services, and modifications in how the existing ones are provided; as well as in their business models. In addition, the new regulations exert a considerable impact on the changes, as they can stimulate market development in various ways. For instance, they can establish new types of payment services providers within the framework of the process of liberalising access to the market (payment institutions, Electronic Money Institutions) through the regulatory opening of the banking infrastructure to non-bank (particularly third-party) entities - this results in the creation of new payment products and business models. Alternatively, regulations aimed at integrating the EU internal market can lead to the creation of new pan-European infrastructures and products.

\subsection{New technologies and business models}

The development of the payment services sector is strongly connected to the development of FinTech, which is described by Leong and Sung (2018, p. 75) as "a cross-disciplinary subject that combines Finance, Technology Management and Innovation Management", and further as "any innovative ideas that improve financial service processes by proposing technology solutions according to different business situations, while the ideas could also lead to new business models or even new businesses". Nevertheless, the term is not understood unambiguously and is still being defined (Butor-Keler \& Polasik, 2020). One of the sub-sectors of FinTech is PayTech (an abbreviation for Payment and Technology), defined as innovative solutions within the framework of retail payments (Polasik et al., 2020, p. 385).

The development of FinTech, including PayTech, has been driven by advances in new technologies such as Artificial Intelligence and the Internet of Things; as well as new communication standards, for example contactless NFC and QR codes. Consumer behaviours, including the common use of electronic banking channels (European Commission, 2018), and the closure of bank branches (European Banking Federation, 2021; Nguyen, 2019), are important factors that govern changes. In recent years, considerable changes in the payment services market have been connected with banks' growing competition from non-bank entities, referred to as PayTechs (Polasik et al., 2020). These entities' operation on a larger scale was guaranteed under PSD2, which introduced the term 'TPP' (Third Party Provider - see Part 2.2).

FinTechs offering innovative payment solutions include: challenger banks (Lu, 2017), PayTech start-ups relying on new business models created mainly owing to the implementation of PSD2, and so-called 'unicorns' - a term describing entities evaluated at more than USD 1 bn (Schueffel, 2017). 
Moreover, the significance of BigTechs has been growing. Stulz (2019) defines them as "technology companies with established presence in the market for digital services". The FinTech category comprises American technological giants, such as Google, Amazon, Facebook and Apple (collectively called GAFA - an abbreviation of the company names), and their Chinese counterparts (so-called BAT - Baidu, Alibaba, Tencent). BigTechs possess considerable competitive power in the whole digital services sector (OECD, 2020), and thus have immense potential to develop in the field of digital payments, where some of them are already significant (Crisanto et al., 2021).

\subsection{EU regulatory policy}

The financial market is subject to numerous regulations, whose scope is constantly expanding. The phenomenon of the growing number of regulations is referred to as 'legal inflation' or the 'regulatory tsunami' (Beck \& Casu, 2016). In the EU, regulatory tools are the major instrument of the implementation of treaty provisions, one of which is the creation of the Single Market. This includes the Single Payments Market, whose establishment had already begun in the 1990s, with such measures as the low harmonisation directive (Directive 97/5/EC, 1997) or recommendation (Commission Recommendation 97/489/EC, 1997). Regulation 2560/2001 (2001) became a crucial accelerator of the implementation of integration-oriented actions, as it forced banks to initiate the self-regulatory process and to build the pan-European payment infrastructure, SEPA. However, the first PSD (PSD1, 2007) - was a high harmonisation directive which introduced a new regulated institution in the form of a payment institution; it also propounded a single approach to the payment service, as well as a single consumer protection standard, which actually accelerated the process (Zalcewicz, 2011).

Simultaneously, the European Payments Council (EPC) designed and introduced SEPA schemes and frameworks as a self-regulation process which had to be supported with SEPA End Date Regulation (EU) 260/2012 (2012), forcing the market participants to migrate to the SEPA standard. One must also mention the Regulation 924/2009 on cross-border payments (2009), which introduced the principle that there is no difference for eurozone citizens and businesses, whether they carry out euro transactions domestically or with another country in the eurozone. It was later amended (Regulation (EU) 2019/518, 2019), forcing all intra-EU cross-border payments in euros to be priced the same as domestic payments in the local currency. Furthermore, interchange fees within the framework of multilateral platforms, to which international payment card systems belong (Rochet \& Tirole, 2003), were also regulated in line with the EU Regulation 2015/751 (2015), so-called MIF Reg.

PSD2, which was implemented in the Polish legal system by the Act on payment services (2011), and Regulatory Technical Standards for strong customer authentication and common and secure open standards of communication 
(Commission Delegated Regulation (EU) 2018/389, 2018), became yet another turning point (Romanova et al., 2018). PSD2 became one of the most progressive payment regulations globally, as it introduced two major innovations. The first comprises the security measures based on Strong Customer Authentication (SCA), while the other is the open banking concept, based on the OpenAPI ${ }^{2}$ infrastructure. Open banking (Basel Committee on Banking Supervision, 2019) enables third-party providers (TPP) to access (with the customer's consent) certain data gathered by banks or other financial institutions (Petrović, 2020). TPP can collect information by means of OpenAPI interfaces, which results in the creation of business models used by PayTechs. Consequently, three new types of services have been introduced under PSD2: (a) PIS - Payment Initiation Service, (b) AIS - Account Information Service, and (c) CAF - Confirmation of the Availability of Funds. Additionally, new types of providers have been established to provide payment services. The results obtained by Polasik et al. (2020) show that the adoption of PSD2 in November 2015 caused a rapid but temporary surge in PayTech start-ups in Europe. Thus, PSD2 positively influenced the increase in the competition from non-bank PayTechs.

\section{Retail Payments Strategy for the EU}

The subject of analysis in this paper, the Strategy, was published in the form of a communication that the European Commission addressed to the European Parliament, the Council, the European Economic and Social Committee, and the Committee of the Regions - as an element of so-called Digital Finance Package, of which the Digital Finance Strategy (2020) is an integral part. ${ }^{3}$

The Strategy identifies key challenges faced by the European payment services market and formulates the vision for its further development, while also identifying the areas that require regulatory intervention. Besides market-related considerations, the document reveals the political goals of the Commission, seeing a need for intensive regulatory intervention in the operation of the market. The Strategy focuses on the private sector and assigns it with developing appropriate payment solutions that would comply with the Commission's vision (Strategy, 2020). This raises the question of whether such profound involvement of a political body in the market's functioning might produce negative

2 OpenAPI — an open, publicly available Application Programming Interface, a basic element of the open banking infrastructure.

3 The Communication from the Commission to the European Parliament, the Council, the European Economic and Social Committee and the Committee of the Regions on a digital finance strategy for the EU (COM/2020/591, 2020) (hereinafter referred to as the Digital Finance Strategy, 2020) was announced on 24 September 2020. The document discusses the major digital innovation trends, defines the strategic objective of embracing digital finance in Europe, and indicates the Commission's priorities in respect of enabling firms and consumers to benefit from digital finance while simultaneously reducing risks. 
results for private initiatives, particularly those entities with considerable innovative and competitive potential.

The Strategy identifies crucial systemic challenges faced by the European payment market. According to the European Commission, they include:

- the dematerialisation of the act of paying and the limitation of bank intermediation;

- the involvement of technological giants in the payment sector (BigTechs);

- the development of crypto-assets, enabling the implementation of payment solutions and Central Bank Digital Currencies (CBDCs);

- a prospective increase in the significance of new payment channels and innovative payment instruments, including those relying on biometrics;

- an increase in the significance of the Internet of Things' intermediation in economic transactions;

- an increase in the number of cashless transactions, with their concurrent further predominance over cash payments.

While identifying the challenges, the Commission attributed them with proposed actions, indicated in the four key pillars of the Strategy: "(1) increasingly digital and instant payment solutions with pan-European reach; (2) innovative and competitive retail payments markets; (3) efficient and interoperable retail payments systems and other support infrastructures; (4) efficient international payments, including remittances" (Strategy, 2020).

Although coordinated by the Commission, the Strategy implementation may involve not only other EU institutions, such as the European Central Bank, but also private entities, including standards bodies such as the European Payments Council. Besides regulatory tools, the Commission may implement the Strategy by resorting to soft law or political persuasion, which it does not exclude from the Strategy itself.

\section{Methods of empirical studies}

The methodological approach adopted in the paper consists of a comparative analysis of the results obtained from the empirical study of market experts, in relation to the European Commission's assumptions and sectoral policy proposed within the framework of the Strategy (2020) adopted in 2020.

The applied research method is based on the consultative approach, which is widely used in the regulatory practice of the European Commission. It involves dialogue with stakeholders to achieve the right balance between regulatory objectives and market needs. In the presented work, future regulatory goals have been extracted from the provisions of the Strategy. In turn, the market's needs were defined through the empirical research under the PayTechImpact.EU project, addressed to market experts in this field. The choice of research method aimed to assess the possibilities of implementing the Strategy, taking into account the current trends in the development of the payment services market and the conditions of a typical regulatory process in the European Union. 
The empirical results were obtained through a survey of experts, including representatives of the European payment sector. The survey was conducted within the framework of the grant awarded by the National Science Centre, titled The impact of the development of FinTech and legal regulations on innovations in the payment services market of the European Union: strategies of the financial sector and consumer needs (2017/26/E/HS4/00858) and led by Prof. Michał Polasik, $\mathrm{PhD}$. The expert survey was conducted in cooperation with chambers of commerce from the European payment sector: the European Banking Federation (EBF), the European Payment Institutions Federation (EPIF), the Polish Bank Association (ZBP), and Febelfin (the Belgian Financial Sector Federation). In addition, the survey was promoted on online expert media, in the form of two popular portals and newsletters: The Paypers (the Netherlands) and FinTech Network (the United Kingdom); and LinkedIn portal, a social network for professionals. Thus, the information about the study reached a vast community of market experts. The study was conducted using the CAWI method on the Nicolaus Copernicus University survey platform in Torun, from March to August 2020. The results obtained were anonymised.

The survey respondents were 202 experts from all EU member states, and from the United Kingdom, Norway and Switzerland. The sample comprises experts employed by both banks and non-bank payment institutions; payment schemes and Automated Clearing Houses, including experts connected with FinTech entities and payment technologies providers; experienced consultants, and representatives of central banks and financial supervisory authorities. The experts recruited for the study were verified in terms of their competencies and experience in the payment services market, to ensure the results' credibility. Furthermore, in order to balance the distribution of the expert participants' replies in terms of the geographical situation of the PayTech experts' community in Europe, a data weighting procedure was applied concerning the countries where the respondents worked.

\section{Research results: challenges for the European payment market}

The results of empirically identified challenges faced by the payment sector are of crucial importance for the purpose of the research conducted in this paper. Experts indicated that Open API implementation was the major challenge to traditional business models in the European payment market at the end of 2020 (Chart 1). In order to tackle the immense scale of implementations, the banking sector made an effort to work out common standards that allow the reduction of Open API implementation-related costs, and the adaptation to comply with the requirements of PSD2 and other regulations. Today, there are five national standardisation initiatives - Open Banking UK (United Kingdom), PolishAPI (Poland), SBAS (Slovakia), STET PSD2 (France) and SIBS API Market (Portugal) - while another, NextGenPSD2/Berlin Group, is pan-European in scope 
(European Payments Council, 2018). An association of over 30 banks and organisations from several European countries, named the Berlin Group initiative, declares its much larger scope of operation, as it "aims to enable a true unbundling of payment schemes and processing activities, as required for providing efficient SEPA payment services to the market" (The Berlin Group, 2021).

This primary challenge was followed by that of customer data protection (47\% of responses) and providing convenient SCA for customers (43\% of responses). Thus, the key challenges to the sector concern implementations connected with current regulatory requirements. Competition against banks and other traditional players was ranked lower (42\%), while competition from non-bank entities did not pose a considerable challenge at the time the survey was conducted (less than $30 \%$ of responses).

However, European experts reckoned that the next five years will see a major change in the significance of particular challenges to the payment services sector (Chart 1). According to them, the largest challenge to traditional business models in the European payment market at the end of 2025 will be competition from non-bank entities - particularly BigTechs (63\% of responses), as well as from new entities and PayTechs (55\% of responses). Equally crucial are the responses pointing to challenges connected with the development of a pan-European payment infrastructure (46\%). Competition between banks and other traditional players was ranked much lower (34\%), and the current key challenges pertaining to the compliance with legal and technical regulations were viewed as significantly less important (fewer than $25 \%$ of responses).

Thus, empirical results show that the experts in the payment sector are generally convinced that competition from BigTechs will become one of the major challenges to traditional business models in the European payment market in the long term. This is not surprising, as the implementation of PSD2 and the development of open banking (compare Part 2.2) has provided technological giants with new possibilities for operating in the financial market. The services using OpenAPI will be able to access the bank accounts of millions of users of other digital services. Owing to this, successful BigTechs - such as Google Pay, Apple Pay or Amazon Pay — will be able to integrate open banking with their own payment services (Kim et al., 2015). A detailed analysis of the survey results confirmed that technology providers, smaller non-bank service providers (PayTechs) and traditional banks are all afraid of the competition from BigTechs. As for the banking sector, pressure from BigTechs seems to be a bigger challenge than competition from new entities and PayTechs; particularly from start-ups, with whom cooperation is mutually beneficial (Drasch et al., 2018).

The assessment of whether the major trends and the most probable scenarios of market development were appropriately identified in the Strategy is crucial for evaluating the accuracy of its assumptions and the actions planned thereunder. Chart 2 shows the experts' assessment of the opportunity arising from the realisation of selected scenarios for the payment services market in Europe, until 2025. A vast majority are of the opinion that global payment card schemes, 
such as Mastercard or Visa, will retain their dominant position in e-commerce within the next five years. On the other hand, almost $60 \%$ of responses indicate that the development of the open banking infrastructure for payments will be the major factor contributing to the development of innovative payment services. This arouses hope that at least some of the intended benefits of PSD2 will be attained.

The conviction that PayTech start-ups will be able to develop payment innovations in a manner that will be better tailored to meet customers' needs than the solutions provided by the banking sector (58\% for 'Definitely yes' and 'Rather yes' responses) demonstrates that one may expect intensified competition in the payment services market (Chart 2). On the other hand, BigTechs may dominate customer relations by providing front-end services and payment services. Undoubtedly, PSD2 gives BigTechs the opportunity to offer financial services on a large scale. Over a half of the experts' responses (56\%) foresee a scenario in which banks will be sidelined as providers of deposits, credits and back-office processes. On the contrary, $55 \%$ of responses maintain that banks will keep their dominant position in servicing customers' retail payments ('Definitely yes' and 'Rather yes' responses). However, it is worth emphasising that a fairly large proportion of responses (25\%) express the opposite opinion, believing that banks can lose their dominant position in the retail payments sector even in this relatively short period. In the context of the above-discussed results, competition between banks and non-bank payment services providers, particularly BigTechs, seems to be the key area of changes in the next five years.

Significant conclusions can be drawn from analysing the anticipated role of particular technologies in the development of payment services over five years (Chart 3). Market experts indicated leading technologies which will have an impact on the payment services provided in two major sectors - e-commerce and Points-Of-Sale (POS). With regard to e-commerce, experts pointed most often to Artificial Intelligence, while instant payments (56\% of responses) are the leading technology directly connected with the payment system and settlements. Other solutions, such as payment cards tokenisation, biometry of behaviour, payments for Internet-Of-Things or blockchain/DLT, were ranked lower (between 25 to $32 \%$ of responses). Thus, the payment sector-related environment is convinced about the major significance of instant payments for the development of payments in e-commerce. It is slightly surprising that the experts predicted that instant payments will soon become the second major payment technology, also at POS (44\% of responses). This confirms the possibility of the universal use of instant payments, which the experts clearly expect to be successful.

On the other hand, experts indicated that contactless/NFC mobile payments will definitely be the leading technology at POS within the next five years $(57 \%$ of responses, Chart 3). Moreover, wearables - which were ranked third (43\% of responses) - are also currently based on NFC, which strengthens the technology's predicted dominance as the data exchange interface at POS. It is note- 
worthy that American BigTechs use NFC for mobile payments in Google Pay and Apple Pay solutions; hence, experts' forecasts must anticipate the further success of these firms. QR codes/optical input were ranked significantly lower (at 36\%). Payment solutions based on QR codes are highly successful in Asia, owing to requiring small outlays on the acceptance infrastructure. Chinese BigTechs, such as Alipay and WeChat, rely on this technology with regard to payments; consequently, a considerable proportion of the responses predict that they will find significant niches for this technology also in Europe. Biometry of the body factor is the last technology, indicated in more than $30 \%$ of responses.

\section{Discussion}

The completion of an independent empirical survey made it possible to carry out expert assessment of the main trends, and of the most probable scenarios of the payment market's development in the upcoming years. It allowed the authors to confront the Strategy for the EU with business reality, and to answer the question of to what extent the actions planned under the Strategy address the challenges faced by the payment cards market in the European Union.

In the Strategy, the European Commission proposed a range of actions oriented towards its implementation and framed in the form of four pillars (compare Part 3). The authors identified the most important actions that directly concern the payment services market, and distinguished five major areas: (i) further development of open banking, (ii) non-bank PSPs' access to the payment infrastructure, (iii) a new approach towards technical services providers supporting payment services, (iv) full implementation of instant payments, and (v) access to necessary technical structure.

\subsection{Further development of open banking}

The Commission highlights the profound significance of PSD2, whose adoption resulted in the appearance of open banking services provided by over 400 nonbanks, as a global point of reference with regard to open banking and secure transactions (Strategy, 2020).

According to the Commission, the potential of open banking has not yet been fully used. The reasons for this include the delay in the implementation of Strong Customer Authentication (SCA), particularly in e-commerce, and the lack of homogeneous standards for application programming interfaces, which is a complication for service providers. At the same time, using regulated services based on access to payment accounts by third-party providers still poses a challenge to regulatory authorities and interested parties (Strategy, 2020). Therefore, this area requires optimisation. Within the framework of the review clause, the Commission will commence a complex overview of the application of PSD2 and its effects at the end of 2021. The Commission is planning to sub- 
mit a legislative proposal in 2022: this will address the new framework of open finance, suggest extending the scope of open banking with other financial services, and will even cover other sectors of the economy.

A comparative analysis of this scope of the Strategy, and the results of empirical research, demonstrates that both the European Commission and market experts consider open banking to be a priority for the development of payment innovations. The Commission identified the significance and potential of open banking, as did the experts who took part in the survey. It should be added that the banking sector has already devoted a huge financial outlay to the implementation of open banking. The actions proposed by the Commission and oriented towards completing the process of the development and optimisation of open infrastructure seem appropriate for taking advantage of this potential. Hence, treating this area as a priority in the Strategy should be evaluated positively.

It should be remembered that the development of open banking can pose a threat to the market position of banks, due to the role of PayTechs and BigTechs. Consequently, further legislation proposals to be submitted by the European Commission should reconcile the interests of all market participants, while also ensuring the market's capacity to create innovation.

\subsection{Access of non-bank providers to bank accounts}

Ensuring that non-bank payment services providers have access to payment infrastructure, particularly offering them the possibility to have a bank account held by a bank, is an important aspect of the creation of an open banking and open finance ecosystem, as well as of a competitive retail payments market. PSD2 obliges the EU member states to guarantee that direct participants (i.e. mainly banks) in a designated payment system subject to the conditions of the Settlement Finality Directive (Directive 98/26/EC, 1998) grant indirect access thereto to payment services providers from outside the banking sector in an objective, proportionate and non-discriminatory manner (PSD2, 2015, Article 35); however, in practice this access tends to be limited, also due to banks' obligations with regard to AML. This prevents electronic money and payment institutions from having direct access to payment systems, and thus from operating. Hence, within the framework of the review of the Settlement Finality Directive (Directive 98/26/EC, 1998), the Commission announced that it would consider an extension of the scope of the SFD so that it would cover electronic money and payment institutions, on condition that they are subject to relevant supervision and limit risk where necessary. This issue will impact the development of open banking.

The action recommended in the Strategy will have a beneficial influence on innovation in the European payment sector, as it will strengthen the stability of PayTechs' operation. This issue was also reflected in the empirical research, which pointed to the high innovativeness of the services offered by PayTechs, and expected the strengthening of these firms' market position. 
According to the empirical research, the availability of open banking infrastructure by 2025 will be the main factor contributing the development of payment innovations. Thus, the actions proposed by the European Commission in this respect should be evaluated positively, as they are focused on developing and using the potential of open banking. Nevertheless, these measures may pose a challenge to banks, which will have to face growing competition from non-bank entities.

\subsection{The new approach of technical services providers supporting the payment service}

Today, the scope of PSD2 does not pertain to the services rendered by 'technical services providers', who support the provision of payment services, though they do not enter into the possession of money while executing a payment transaction. Consequently, this type of activity cannot be treated as a payment service (PSD2, 2015, Article 3 letter j).

Technical services providers include technological giants (BigTechs) which participate in providing a payment service. In this context, the European Commission notices many risks connected with a growing share of these entities in the European payment market. In particular, it highlights their current role in the payment chain as providers of front-end solutions (compare Chart 2, Part 5), which - in connection with new business models - does not require them to operate under the supervisory regime of the banking sector. Moreover, the Commission is afraid that a broader entrance of BigTechs into financial services markets may strengthen the network effects and these giants' market power (Strategy, 2020), to the disadvantage of European providers. Therefore, according to the Commission, BigTechs should be subject to a regulation, in compliance with the principle "same business, same risks, same rules" (Strategy, 2020).

In the Strategy, the Commission defines the term 'payments conglomerate', pertaining to both regulated and unregulated entities providing technical services to support some of the group affiliates. According to the Commission, the bankruptcy of an unregulated entity from the conglomerate may have a negative impact on regulated subsidiaries. Consequently, while reviewing PSD2, the Commission is planning to assess whether some of these services and service providers should be brought into the regulated sphere and made subject to supervision. The Commission will also assess the adequacy of the exemptions listed in PSD2, and will evaluate the need for changes in prudential, operational and consumer protection requirements.

A majority of the Commission's findings concerning technical services providers pertains to the challenges connected with the operation of BigTechs. The Commission aptly notices the fact that the development of BigTechs in the payment services market poses a serious challenge to European entities. It also recognises risks regarding the asymmetry between BigTechs and other 
entities doing business in the payment services market. The empirical research resulted in a similar diagnosis of the market situation. According to the experts, competition with BigTechs will pose the major challenge to traditional business models in the European payment market at the end of 2025 (63\% of responses, Chart 1). Therefore, the Commission's reaction seems to be justified, even though the regulatory mechanism applied may arouse doubts.

The Commission proposes the introduction of regulations pertaining to payments conglomerates, and aimed at preventing risks connected with the development of BigTechs. However, in light of the empirical research, this proposal does not address these challenges sufficiently. There exists a concern that imposing regulations on and exercising supervision over all entities providing solely technical services may, paradoxically, strengthen the position of BigTechs, to the disadvantage of small providers, as they would also comply with new requirements. If smaller IT companies withdraw from the payment market, they will leave room for technological giants with considerable financial resources. Thus, the Commission should seek alternative solutions. Another approach may be applying the principle of proportionality; this would involve excluding from the new regime, or reducing requirements for, technical services providers that are not considered 'critical' to the payment system, and specifically that have no systemic influence over the provision of the payment services and the payment service providers. To conclude, it seems that the Commission's response to the challenges from BigTechs, planned for development in the course of revising the PSD2 regulation, may benefit from considering the above-mentioned criteria.

\subsection{Full implementation of instant payments}

The Strategy dedicates much space to the significance of instant payments, which form part of the first pillar. The Commission's objective is to implement an instant payments scheme in the European Union by the end of 2021. According to the Commission, to achieve this goal, it is necessary to make advances at three levels: rules, end-user solutions, and infrastructures.

Concerning the same regulations, the Strategy highlights that the SEPA instant payment scheme has not yet been implemented by many payment services providers. For example, in August 2020, which was almost three years after the introduction of SEPA, only $62.4 \%$ of all EU payment services providers offering SEPA credit transfers had joined the scheme (Strategy, 2020). Accordingly, it may be necessary to legally require entities to participate in the SCT Instant Scheme.

However, regarding the solutions for end-users, it was concluded that it is crucial to ensure the interoperability and availability of payment solutions. Nevertheless, the planned key actions in this respect indicated by the Commission include merely the assessment of whether the obligation to participate 
in the SEPA Scheme should pertain to all or only some functions; for example, those concerning QR codes, SEPA Proxy Lookup or Request-to-pay.

The Commission also indicated that the current international infrastructure should become wholly interoperable. The solution to this problem should be the resources allocated to ensure the pan-European scope of instant payments in euros by the end of 2021, and announced by the European Central Bank in the communication of 24 July 2020 (ECB, 2020).

The Commission is also planning to undertake actions oriented towards increasing consumers' trust in instant payments. In this context, the Commission is planning to review PSD2 in respect of ensuring the same protection for consumers as in the case of other instruments, including payment cards. In particular, an analysis of the influence of charge on instant payments will be conducted, which may lead to the establishment of a maximum charge that will not be higher than that for regular credit transfers - as occurred in the case of cross-border payments in euros under Regulation 2560/2001 (2001).

In addition, the Commission reveals that the instant payments infrastructure should constitute the basis for creating pan-European payment solutions, which are expected to compete with non-European solutions present in the internal market. This important political goal is often mentioned in the Strategy. Nevertheless, it should be remembered that the Commission's political visions should comply with the EU competition law and should not lead to the weakening of strongly innovative national solutions. The history of SEPA implementation shows that searching for a common denominator is not conducive to innovation (The Global Treasurer, 2005).

With regard to the role of instant payments as payment technologies, market experts expect a considerable increase in their significance, as does the Commission. As provided in the Strategy, the Commission intends to strongly support the development of instant payments, which should be endorsed. This field has considerable potential to develop. The empirical research shows that by 2025 this technology will be of major importance to the development of payments in both e-commerce and at POS (see Chart 3). Simultaneously, the Commission notices the several risks that can discourage consumers from using instant payments. Should the Commission's actions lead to an increase in consumers' trust, their effect will be positive. However, overregulation may be counterproductive and hinder the development of instant payments.

\subsection{Access to necessary technical infrastructure}

A major part of the Strategy was dedicated to the creation of a single, interoperative EU payment infrastructure with a special emphasis on mobile contactless payments. The empirical research shows that infrastructure development will be one of the major challenges to the payment sector by 2025 (Chart 1). The Commission particularly highlighted the problem of restricted access to the necessary technical infrastructure and mobile devices software offered 
by one of the leading manufacturers. The problem concerns especially the following technical elements: non-public layers built into the operational systems of mobile devices (including Near-Field Communication antennas - NFC); biometric readers, such as fingerprint scanners or face recognition readers; application shops; and operating system kernels at POS, SIM cards, etc. Apart from resorting to the instruments of competition law, in this case the Commission will consider a regulatory option in the form of provisions aimed at ensuring the right of access, on just, reasonable and non-discriminatory conditions, to the technical infrastructure considered to be necessary to support the provision of payment services.

The above-described actions are good examples of caring about the interoperability and openness of the payment infrastructure in the broad sense. The fact that the Commission pointed to the NFC should be perceived positively, because - as the survey results show - it will be the most important technology used in POS payments. The empirical results point to contactless payments and, further, to QR codes as the technologies that will develop fastest in Europe (Chart 3). Enhancing the entire infrastructure will contribute to the development of the financial market, while interoperability may stimulate innovation. However, as no direct measures were proposed in the Strategy, the likelihood of achieving the objectives as planned is in doubt.

\section{Conclusion}

The research conducted identified the key objectives set out by the European Commission in its Strategy (Q1), which include: (i) further development of open banking, (ii) ensuring non-bank providers' access to the banking payment infrastructure, (iii) countering the risks of BigTechs' operation, (iv) full implementation of instant payments, and (v) ensuring access to the necessary payment infrastructure. In contrast, the actions that the Commission intends to take in order to achieve these objectives are set out in varying degrees of detail in the Strategy. A considerable part of these actions will comprise legislative initiatives, the details of which the Commission does not specify at this stage, stating that such initiatives should be preceded by analyses, including assessment of PSD2's impact. Other actions are of a less decisive nature, and especially concern supporting the work of other EU bodies or conducting studies in a specific area. Only a small proportion of the actions announced in the Strategy mentions specific solutions to be implemented within a given time.

The empirical research (Q2) demonstrates that by 2025 the two biggest challenges will relate to (a) competition from non-banks, and (b) the development of payment infrastructure. As for the payment market, the issues of crucial importance will be growing competition for the banking sector from BigTechs, which have several advantages in the digital services market; and, on the other hand, the dynamic development of non-bank providers, such as PayTechs. Most experts tend to believe that in five years, banks will maintain their current 
leading position in the provision of retail payment services; yet they also consider radical scenarios of market changes. According to the experts, the expansion of the pan-European payment infrastructure and the further development of open banking will be essential for the development of payment innovation in Europe. The payment sector shares the belief in the leading role and universal applications of instant payments, which stand a great chance of becoming a platform for the dynamic development of European payment innovations. With regard to POS payments, the most important technologies will be contactless and mobile NFC, while QR codes will be less popular.

When comparing the Commission's approach with the challenges identified by the market experts $(\mathrm{Q} 3)$, it is important to highlight the different perspective of the Commission as a body representing the public sector; it thus pursues not only tasks to promote the development of the market and its participants, but also political objectives. In the case of the payment market, these include: (a) the integration of the EU payment market; and (b) empowering European payment services solutions, systems and providers to face competition from geopolitical rivals.

When assessing the Strategy prepared by the EC, it should be stated that the areas of main challenges and opportunities for development identified therein were in line with the results of empirical research. The Commission devotes relatively more attention to infrastructure development-related issues than to the issue of market competition and the role of new players - namely, BigTechs and PayTechs, with increased competition from the latter being a phenomenon desired by the Commission. Furthermore, it should be noted that while there is general agreement regarding the important challenges identified for the payment sector, the manner of addressing them is a separate issue. The Strategy foresees an increasing use of regulatory tools, which may be justified in selected cases. However, the Commission does not sufficiently recognise the need to stimulate the development of new payment solutions, which may result in insufficient development dynamics for European payment innovations.

For BigTechs, the Commission notices the risks resulting from these players' involvement in the payment market; nevertheless, it does not propose comprehensive solutions in this regard. As suggested in the Strategy, the actions aimed at regulating BigTechs' operation in the payment market, as providers of technical solutions supporting the payment service, may paradoxically affect smaller players that will not be able to adapt to the new requirements.

The conclusions drawn from the research allow the authors to formulate three practical recommendations. The first is to pursue optimisation of the open banking infrastructure's operation, in order to remove current barriers particularly those that limit the creation of new solutions by third parties. The second is a proposal to extend the scope of open banking to other services, and probably even to other areas of the financial sector, to pursue the vision of open finance. The third recommendation is to work out an effective response to BigTech-related challenges, given that despite having accurately diagnosed 
the potential risks associated with the entry (in various roles) of this category of players into the payment services market, the Commission did not propose a systemic and comprehensive approach to address this challenge in the current Strategy. Each of the above issues deserves more in-depth research in the future.

\section{References}

Basel Committee on Banking Supervision. (2019). Report on open banking and application programming interfaces. Retrieved 13.07.2021 from https://www. bis.org/bcbs/publ/d486.pdf.

Bech, M., \& Hancock, J. (2020). Innovations in payments. BIS Quarterly Review, March, 1-16.

Beck, T., Casu, B. (Eds.). (2016). The Palgrave handbook of European banking. Palgrave Macmillan. https://doi.org/10.1057/978-1-137-52144-6.

Blind, K., Petersen, S.S., \& Riillo, C.A.F. (2017). The impact of standards and regulation on innovation in uncertain markets. Research Policy, 46(1), 249-264. https://doi.org/10.1016/j.respol.2016.11.003.

Butor-Keler, A., Polasik, M. (2020). The role of regulatory sandboxes in the development of innovations on the financial services market: the case of the United Kingdom. Ekonomia i Prawo. Economics and Law, 19(4), 621638. https://doi.org/10.12775/EiP.2020.041.

Commission Delegated Regulation (EU) 2018/389 of 27 November 2017 supplementing Directive (EU) 2015/2366 of the European Parliament and of the Council with regard to regulatory technical standards for strong customer authentication and common and secure open standards of communication (OJ L 69, 13.3.2018).

Commission Recommendation 97/489/EC of 30 July 1997 concerning transactions by electronic payment instruments and in particular the relationship between issuer and holder (OJ L 208, 2.8.1997).

Communication from the Commission to the European Parliament, the Council, the European Economic and Social Committee and the Committee of the Regions on a digital finance strategy for the EU (COM/2020/591 final) [Digital Finance Strategy, 2020].

Communication from the Commission to the European Parliament, the Council, the European Economic and Social Committee and the Committee of the Regions on a retail payments strategy for the EU (COM/2020/592 final) [Strategy, 2020].

Consolidated version of the Treaty on the Functioning of the European Union (OJ C 326, 26.10.2012).

Crisanto, J.C., Ehrentraud, J., \& Fabian, M. (2021). Big techs in finance: regulatory approaches and policy options. FSI Briefs, 12, 1-15. 
Directive 2007/64/EC of the European Parliament and of the Council of 13 November 2007 on payment services in the internal market amending Directives 97/7/EC, 2002/65/EC, 2005/60/EC and 2006/48/EC and repealing Directive 97/5/EC (OJ L 319, 5.12.2007) [PSD1, 2007].

Directive (EU) 2015/2366 of the European Parliament and of the Council of 25 November 2015 on payment services in the internal market, amending Directives 2002/65/EC, 2009/110/EC and 2013/36/EU and Regulation (EU) No 1093/2010, and repealing Directive 2007/64/EC (OJ L 337, 23.12.2015). [PSD2, 2015].

Directive 97/5/EC of the European Parliament and of the Council of 27 January 1997 on cross-border credit transfers (OJ L 43, 14.2.1997).

Directive 98/26/EC of the European Parliament and of the Council of 19 May 1998 on settlement finality in payment and securities settlement systems (OJ L 166, 11.6.1998).

Drasch, B.J., Schweizer A., \& Urbach N. (2018). Integrating the "troublemakers': a taxonomy for cooperation between banks and fintechs. Journal of Economics and Business, 100, 26-42. https://doi.org/10.1016/j. jeconbus.2018.04.002.

ECB. (2020). ECB takes steps to ensure pan-European reach of instant pay-ments. Retrieved 23.08.2021 from https://www.ecb.europa.eu/paym/intro/news/ html/ecb.mipnews200724.en.html.

European Banking Federation. (2021). Structure of the banking sector. Retrieved 13.07.2021 from https://www.ebf.eu/facts-and-figures/ structure-of-the-banking-sector.

European Commission. (2018). Internet banking on the rise. Retrieved 13.07.2021 from https://ec.europa.eu/eurostat/web/products-eurostat-news/- / DDN-20180115-1.

European Payments Council. (2018). Summary of the API evaluation workshop. Retrieved 23.08.2021 from https://www.europeanpaymentscouncil.eu/ sites/default/files/kb/file/2018-04/API\%20EG\%20019-18\%20vl.1\%20 Summary\%20of\%20the\%20API\%20Evaluation\%20Workshop\%20 - \%20 20180228.pdf.

Kim, Y., Pakr, Y.-J., Choi, J., \& Yeon, J. (2015). An empirical study on the adoption of "fintech" service: focused on mobile payment services. Advanced Science and Technology Letters, 114, 136-140. http://dx.doi.org/10.14257/ astl.2015.114.26.

Leong, K., \& Sung, A. (2018). FinTech (financial technology): what is it and how to use technologies to create business value in fintech way. International Journal of Innovation, Management and Technology, 9(2), 74-78. https://doi. org/10.18178/ijimt.2018.9.2.791.

Lu, L. (2017). Financial technology and challenger banks in the UK: gap fillers or real challengers. Journal of International Banking Law and Regulation, 32(7), 273-282. 
Mavromati, D. (2008). The law of payment services in the EU: the EC directive on payment services in the internal market. Wolters Kluwer.

Nguyen, H.L.Q. (2019). Are credit markets still local: vidence from bank branch closings. American Economic Journal: Applied Economics, 11(1), 1-32, https://doi.org/10.1257/app.20170543.

OECD. (2020). Digital disruption in banking and its impact on competition. Retrieved 13.07.2021 from https://www.oecd.org/competition/digital-disruption-in-banking-and-its-impact-on-competition-2020.pdf.

Petrović, M. (2020). PSD2 influence on digital banking transformation: bank's perspective. Journal of Process Management: New Technologies, International, $8(4), 1-14$.

Polasik, M., Huterska, A., Iftikhar, R., Mikula, Š. (2020). The impact of Payment Services Directive 2 on the PayTech sector development in Europe. Journal of Economic Behavior \& Organization, 178, 385-401. https://doi. org/10.1016/j.jebo.2020.07.010.

Regulation (EC) No 2560/2001 of the European Parliament and of the Council of 19 December 2001 on cross-border payments in euro (OJ L 344, 28.12.2001).

Regulation (EC) No 924/2009 of the European Parliament and of the Council of 16 September 2009 on cross-border payments in the Community and repealing Regulation (EC) No 2560/2001 (OJ L 266, 9.10.2009).

Regulation (EU) 2015/751 of the European Parliament and of the Council of 29 April 2015 on interchange fees for card-based payment transactions (OJ L 123, 19.5.2015).

Regulation (EU) 2019/518 of the European Parliament and of the Council of 19 March 2019 amending Regulation (EC) No 924/2009 as regards certain charges on cross-border payments in the Union and currency conversion charges (OJ L 91, 29.3.2019).

Regulation (EU) No 260/2012 of the European Parliament and of the Council of 14 March 2012 establishing technical and business requirements for credit transfers and direct debits in euro and amending Regulation (EC) No 924/2009 (OJ L 94, 30.3.2012).

Rochet, J.-C., \& Tirole, J. (2003). Platform competition in two-sided markets. Journal of the European Economic Association, 1(4), 990-1029. https://doi. org/10.1162/154247603322493212.

Romanova, I., Grima S., Spiteri, J., \& Kudinska, M. (2018). The Payment Services Directive II and competitiveness: the perspective of European fintech companies. European Research Studies Journal, 21(2), 3-22. https://doi. org/10.35808/ersj/981.

Schueffel, P. (2017). The concise fintech compendium. School of Management Fribourg.

Stulz, R.M. (2019). FinTech, BigTech and the future of banks. NBER Working Paper Series, 26312, 1-26. https://doi.org/10.3386/w26312. 
The Berlin Group. (2021). PSD2 access to bank accounts. Retrieved 23.08.2021 from https://www.berlin-group.org/psd2-access-to-bank-accounts.

The Global Treasurer. (2005). Payments of the future and the future of payments. Retrieved 23.08.2021 from https://www.theglobaltreasurer. com/2005/10/25/payments-of-the-future-and-the-future-of-payments.

Ustawa z dnia 19 sierpnia 2011 r. o usługach płatniczych [Act of 19 August 2011 on payment services] (Dz.U. 2011 nr 199 poz. 1175) (Poland).

Zalcewicz, A. (2011). Proces integracji europejskiego rynku usług płatniczych: wyzwania regulacyjne. Ekonomia i Prawo. Economics and Law, 7(1), 321-340. https://doi.org/10.12775/EiP.2011.020.

\section{Acknowledgements}

Author contributions: authors have given an approval to the final version of the article. Authors contributed to this work as follows: M.P., P.W., G.K. and A.B-K. developed the concept and designed the study, M.P. collected the data, M.P., P.W., G.K. and A.B-K. analysed and interpreted the data, M.P., P.W., G.K. and A.B-K. prepared the draft of the article and revised the article critically for important intellectual content.

Funding: This research was supported by the National Science Centre of Poland under grant (2017/26/E/HS4/00858).

Disclaimer: The views expressed in the article are the personal views of the authors (Agnieszka Butor-Keler, Paweł Widawski) and do not express the official position of the institution which they are employed by. 


\section{Appendix}

\section{Chart 1.}

The biggest challenges for traditional business models in the European payment market, by the end of 2020 and 2025 (in \%)

implementation of open API

customer data protection

provision of convenient SCA for customers

competition against banks \& other traditional players

competition against new players/PayTechs

competition against BigTech (GAFA, BAT

or mass customer base players)

developing pan-European payment

infrastructure

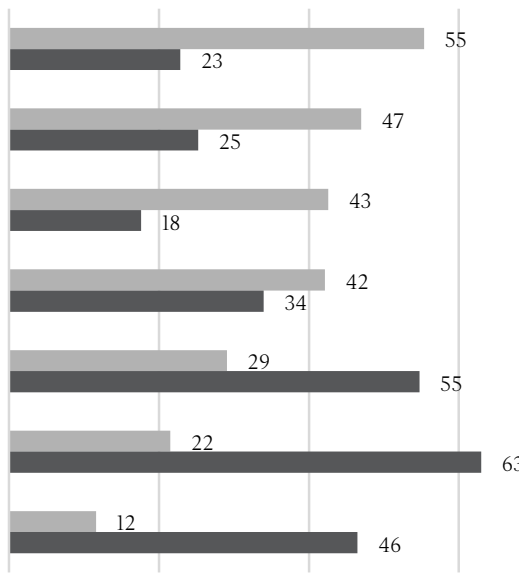

0

— by the end of 2020
20

40

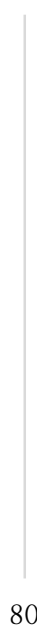

ש by the end of 2025

Note:

Q: Please indicate the biggest challenges* for traditional business models** in the European payment market (please choose a maximum of five answers for a given time-span).

By the end of 2020, N=172; By the end of 2025, N=193.

Expert survey; Preliminary results

* Selected Top 5 major challenges for the 2020 and 2025 time-span, respectively, excluding Cybersecurity and Maintaining strong customer relationship as challenges pertaining to general business rather than just the sector.

** Traditional business models refer to pre-PSD2 roles in the European payment market.

Source: Own preparation. 


\section{Chart 2.}

\section{Future scenarios that may occur in the 2025 perspective (in \%)}

Global payment card schemes will be a main payment solution in e-commerce and m-commerce in EEA.

Development of an open banking infrastructure for payment solutions will be the main factor behind the development of payment innovations.

Payment innovations developed by PayTech startups will be better-suited to customer needs than solutions introduced by the banking sector.

BigTechs will be the front end in providing payment services, but deposits, credits and net transfers will still be provided by banks.

Banks will remain dominant in servicing payments for retail clients.

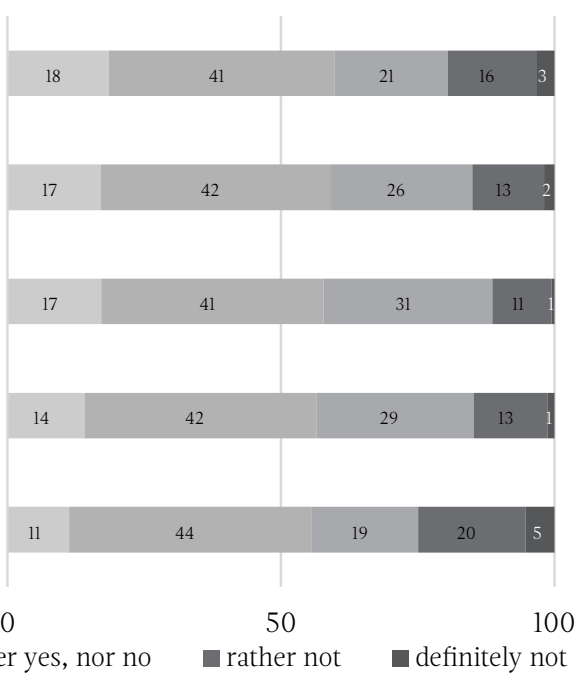

\footnotetext{
definitely yes $\square$ dather yes $\square$ deither yes, nor no
}

rather not

definitely not

Notes:

Q: What future scenarios may occur in the 2025 perspective?

$\mathrm{N}=201$.

Source: Own preparation. 


\section{Chart 3.}

The technologies that will have the biggest impact on the development of payment services by the end of 2025 (in \%)

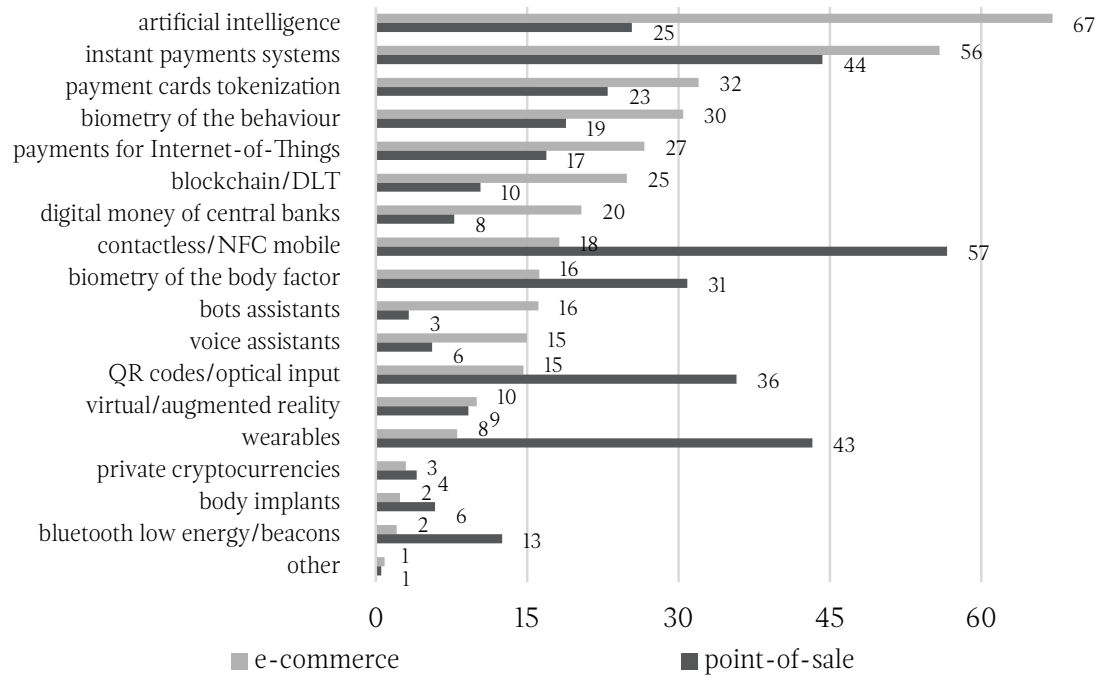

Notes:

Q: Please indicate the technologies that will have the biggest impact on the development of payment services by the end of 2025 (please choose a maximum of three answers for each market segment).

E-commerce, $\mathrm{N}=201$; Point-Of-Sale, $\mathrm{N}=200$.

Source: Own preparation. 